\title{
PENGARUH QUALITY OF WORK LIFE DAN PENGGUNAAN TEKNOLOGI INFORMASI TERHADAP PERILAKU KERJA INOVATIF DOSEN YANG DIMEDIASI KOMITMEN ORGANISASI (Studi pada Dosen Politeknik Pusmanu Pekalongan)
}

\author{
${ }^{1)}$ Aria Elshifa, ${ }^{2)}$ Ari Dwi Anjarini, ${ }^{3)}$ Aghus Jamaludin Kharis \\ 1) Politeknik Pusmanu Pekalongan \\ Sekertariat PCNU Kabupaten Pekalongan Jl. Karangdowo No. 9 Kedungwuni \\ Email: elshifapusmanu@gmail.com \\ ${ }^{2)}$ Politeknik Pusmanu Pekalongan \\ Sekertariat PCNU Kabupaten Pekalongan Jl. Karangdowo No. 9 Kedungwuni \\ Email: arydwianjarini@politeknikpusmanu.ac.id \\ 3) Politeknik Pusmanu Pekalongan \\ Sekertariat PCNU Kabupaten Pekalongan Jl. Karangdowo No. 9 Kedungwuni \\ Email: haris-spider@yahoo.com
}

\begin{abstract}
The purpose of this study is to determine and analyze the effect of quality of work life and the use of information technology on organizational commitment. Knowing and analyzing the effect of quality of work life, use of information technology and organizational commitment to innovative work behavior of lecturers. The population in this study were 34 lecturers at Pusmanu Pekalongan Polytechnic. The results of the study can be concluded as follows: quality of work life and the use of information technology have a positive and significant effect on organizational commitment of Pusmanu Pekalongan Polytechnic lecturers. Quality of work life, the use of information technology and organizational commitment have a positive and significant effect on the innovative work behavior of Pusmanu Pekalongan Polytechnic lecturers. Organizational commitment as a variable that intervenes the influence of quality of work life and the use of technology on innovative work behavior of Pusmanu Pekalongan Polytechnic lecturers.
\end{abstract}

Keywords: Quality of Work Life, The use of Information Technology, Organizational Commitment, Innovative Work Behavior of Lecturers.

\section{ABSTRAK}

Tujuan penelitian ini adalah mengetahui dan menganalisis pengaruh quality of work life dan penggunaan teknologi informasi terhadap komitmen organisasional. Populasi dalam penelitian ini adalah adalah Dosen Politeknik Pusmanu Pekalongan adalah 34 orang. Hasil penelitian dapat diperolehquality of work life dan penggunaan teknologi informasi berpengaruh positif dan signifikan terhadap komitmen organisasional dosen Politeknik Pusmanu Pekalongan. Quality of work life, penggunaan teknologi informasi dan komitmen organisasional berpengaruh positif dan signifikan terhadap perilaku kerja inovatif dosen Politeknik Pusmanu Pekalongan. Komitmen organisasional sebagai variabel yang mengintervening pengaruh quality of work life dan penggunaan teknologi terhadap perilaku kerja inovatifdosen Politeknik Pusmanu Pekalongan.

Kata kunci: Quality of Work Life, Penggunaan Teknologi Informasi, Komitmen Organisasional, Perilaku Kerja Inovatif Dosen.

\section{PENDAHULUAN}

\subsection{Latar Belakang}

Tuntutan profesionalisme akibat dari perubahan global sesuai dengan tuntutan perubahan masyarakat, Pemerintah Indonesia memiliki tanggungjawab mengembangkan sistem pengelolaan serta menggunakan kewenangannya menyiapkan SDM unggul lewat pembenahan sistem pendidikan nasional. Undang-Undang Republik Indonesia Nomor 14 Tahun 2005 tentang Guru dan Dosen merupakan dasar hukum penyelenggara pendidikan yang dilakukan secara profesional. 
Bahwa seorang dosen profesional dituntut sejumlah persyaratan, antara lain memiliki kualifikasi pendidikan profesi dan kompetensi keilmuan, memiliki kemampuan berkomunikasi yang baik dengan mahasiswanya, mempunyai jiwa kreatif dan produktif, mempunyai etos kerja dan komitmen yang tinggi terhadap profesinya serta selalu melakukan pengembangan diri secara terus-menerus. Akan tetapi, dalam pelaksanaannya penuh dengan keterbatasan secara institusional.

Beberapa permasalahan tersebut berkisar pada persoalan kurang memadainya kualifikasi dan kompetensi dosen, kurangnya tingkat kesejahteraan dosen, rendahnya etos kerja dan komitmen dosen serta kurangnya penghargaan masyarakat terhadap profesi dosen. Dalam konteks perilaku keorganisasian, persoalan yang terungkap di atas yang mana seorang dosen dihadapkan dengan tuntutan peran profesinya, dan di lain pihak adanya keterbatasan yang dimilik oleh dosen itu sendiri maupun keterbatasan akan apa yang diharapkan untuk diperoleh dari profesinya sangat berkaitan dengan peran penting dari seorang dosen dalam organisasi sekolah, khususnya perilaku kerja inovatif. Masih sebagian dosen dalam mengajar tidak menunjukan perilaku kerja inovatif, antara lain metode pengajaran beberapa dosen yang masih konvensional, tidak ada pembagian pengetahuan tentang metode pembelajaran yang tepat.

Perilaku kerja inovatif dosen yang akan mendorong tercapainya tujuan pembelajaran di Perguruan Tinggi. Dosen yang berperilaku kerja inovatif akan selalu mempunyai hal-hal baru untuk diberikan ke mahasiswa, sehingga kehadirannya selalu dinantikan oleh mahasiswa. Mahasiswa dengan penuh semangat selalu menantikan saat pertemuan selanjutnya dengan dosen yang bersangkutan. Pada posisi yang demikian, dosen yang inovatif dijadikan figur sentral oleh mahasiswa dalam hal minat dan semangat belajar, terutama dalam hal mata kuliah yang diampu oleh dosen tersebut.

Untuk itu, dosen Politeknik Pusmanu Pekalongan harus dapat diberdayakan agar mereka memiliki nilai lebih dalam arti lebih mampu, lebih terampil dan lebih berkualitas agar dapat berdaya guna secara optimal dalam pembangunan nasional dan mampu bersaing dalam era globalisasi. Untuk meningkatkan Perilaku kerja inovatif dosen, maka pihak Politeknik Pusmanu Pekalongan harus selalu menggali faktorfaktor yang dapat mempengaruhi Perilaku kerja inovatif para dosen.

Untuk meningkatkan perilaku kerja inovatif dosen, maka perlu diperhatikan faktor quality work life (QWL). Quality of work life (QWL) mengacu pada keadaan menyenangkan atau tidak menyenangkannya lingkungan pekerjaan bagi seseorang. Tujuan utamanya adalah pengembangan lingkungan kerja yang sangat baik. Fokus utama dari Quality of Work Life sendiri adalah bahwa lingkungan kerja dan semua pekerjaan didalamnya harus sesuai dengan orang-orang dan teknologi (Davis dan Newstrom, 2004).

Di dalam institusi pendidikan seperti di Politeknik Pusmanu, salah satu cara yang di tempuh untuk meningkatkan dosen memiliki perilaku kerja inovatif dosen adalah dengan peningkatan kualitas kehidupan kerja quality of work life (QWL), karena dengan cara ini dosen akan betah dan nyaman dalam bekerja. Segala kebutuhan baik itu materi maupun psikologis dapat terpenuhi.

Hal ini sejalan dengan pendapat yang dikemukan oleh Sumarsono (2004) menjelaskan quality of work life sebagai salah satu pendekatan sistem manajemen untuk mengkoordinasikan dan menghubungkan potensi SDM dalam organisasi, sebagai salah satu upaya pimpinan untuk memenuhi kebutuhan anggota maupun organisasi secara simultan dan terus menerus. 
Faktor Penggunaan teknologi informasi mempengaruhi perilaku kerja inovatif dan kinerja pegawai. Menurut Kadir dan Triwahyuni (2013) "Teknologi informasi adalah seperangkat alat yang membantu seseorang bekerja dengan informasi dan melakukan tugas yang berhubungan dengan pemprosesan informasi". Hal ini dijelaskan bahwa teknologi informasi merupakan suatu gabungan antara teknologi komputer dan teknologi komunikasi. Teknologi komputer merupakan seperangkat peralatan yang digunakan untuk mengubah data menjadi suatu informasi yang dapat menjadi bahan dalam pengambilan keputusan. Sedangkan kegunaan utama teknologi informasi secara global adalah membantu dalam pemecahan masalah dengan kreatifitas tinggi dan membuat manusia semakin efektif dalam memanfaatkannya.

Penggunaan Teknologi Informasi (TI) untuk mendukung berbagai kebutuhan dan perkembangan organisasi dan individu tentu akan mendatangkan sesuatu yang positif. Namun perlu diketahui bahwa TI dapat membuat seorang pegawai menjadi lebih berarti dengan penggunaannya untuk hal yang positif. Pengguna Teknologi Informasi (TI) akan mempengaruhi sikap seorang pegawai dalam penerimaan terhadap teknologi tersebut. Salah satu faktor yang dapat mempengaruhinya adalah persepsi pengguna terhadap kemanfaatan dan kemudahan penggunaan TI sebagai suatu tindakan yang beralasan dalam konteks pengguna teknologi. Jika penggunaan TI memberikan manfaat membantu pekerjaan. Dengan demikian penggunaan teknologi informasi berpengaruh terhadap perilaku kerja inovatif.

Faktor lain yang mempengaruhi perilaku kerja inovatif dosen adalah komitmen dosen pada organisasi. Komitmen organisasional merupakan salah satu topik yang selalu menarik untuk dikaji dan diteliti karena paling banyak diamati sekaligus fenomena yang paling sedikit dipahami. Komitmen organisasional merupakan ukuran kekuatan identifikasi anggota organisasi dengan tujuan dan nilai organisasi serta terlibat di dalamnya, komitmen oganisasi juga menjadi indikator yang lebih baik bagi anggota organisasi yang ingin tetap pada pekerjaannya atau ingin pindah (Smith dalam Rahmad, 2013).

Fenomena-fenomena yang terjadi mengenai quality of work life, penggunaan teknologi informasi perilaku kerja inovatif dan komitmen organisasional pada dosen Politeknik Pusmanu Pekalongan sebagai berikut :

1. Quality of work life berdasarkan aspek lingkungan kerja dan partisipasi kerja yang belum sesuai dengan harapan para dosen, dimana masih ada dosen merasa tidak nyaman dalam bekerja, masih ada dosen tidak dilibatkan untuk berpartisipasi dalam kegiatan yang ada di Politeknik Pusmanu. Berdasarkan aspek Quality of work life tersebut menyebabkan perilaku dosen dalam bekerja menjadi kurang inovatif.

2. Faktor penggunaan teknologi informasi juga sebagai penyebab perilaku kerja inovatif belum optimal. Hal tersebut diindikasikan masih ada dosen yang belum dapat menggunakan teknologi informasi dalam pelaksanaan tugasnya sesuai yang diharapkan.

3. Masih ada dosen memiliki perilaku kerja dalam organisasi yang kurang inovatif, hal tersebut dapat dilihat dari belum mampu melakukan perubahan sistem pembelajaran tepat.

4. Sebagian dosen kurang memiliki komitmen organisasional yang tinggi ditunjukkan dengan loyalitas dosen terhadap organisasi yang rendah. Perilaku ini disebabkan karena seringnya perubahan kebijakan yang diterapkan oleh pimpinan. 


\subsection{Tujuan Masalah}

Berdasarkan latar belakang yang telah diuraikan sebelumnya, maka tujuan masalah penelitian ini adalah:

1. Mengetahui dan menganalisis pengaruh quality of work life dengan komitmen organisasional.

2. Mengetahui dan menganalisis pengaruh penggunaan teknologi informasi dengan komitmen organisasional.

3. Mengetahui dan menganalisis pengaruh quality of work life dengan perilaku kerja inovatif.

4. Mengetahui dan menganalisis pengaruh penggunaan teknologi informasi dengan perilaku kerja inovatif.

5. Mengetahui dan menganalisis pengaruh komitmen organisasional dengan perilaku kerja inovatif.

6. Mengetahui dan menganalisis pengaruh tidak langsung quality of work life terhadap perilaku kerja inovatif melalui komitmen organisasional.

7. Mengetahui dan menganalisis pengaruh tidak langsung teknologi informasi terhadap perilaku kerja inovatif melalui komitmen organisasional.

\section{TINJAUAN PUSTAKA}

\subsection{Landasan Teori}

\subsubsection{Quality of Work Life}

Quality of Work Life (QWL) mengacu pada keadaan menyenangkan atau tidak menyenangkannya lingkungan pekerjaan bagi seseorang. Tujuan utamanya adalah pengembangan lingkungan kerja yang sangat baik bagi karyawan dan juga bagi produksi. Fokus utama dari Quality of Work Life sendiri adalah bahwa lingkungan kerja dan semua pekerjaan didalamnya harus sesuai dengan orangorang dan teknologi (Davis dan Newstrom, 1994). Kemudian Sumarsono (2004) mendefinisikan Quality of Work Life sebagai salah satu pendekatan sistem manajemen

untuk mengkoordinasikan dan menghubungkan potensi SDM dalam organisasi, sebagai suatu upaya pimpinan untuk memenuhi kebutuhan anggota maupun organisasi secara simultan dan terus menerus.

Koontz dan Weihrich mendefinisikan quality of work life sebagai suatu sistem yang mengarah pada desain pekerjaan dan suatu pengembangan pada semua bidang, yaitu pemerkayaan pekerjaan (job enrichment) yang dihubungkan dengan tujuan dari sistem sosio-teknis yang mengarah pada manajemen. Quality of work life bukan hanya sebagai pendekatan mengenai pemerkayaan dan pemekaran pekerjaan saja melainkan Quality Of Work Life sebagai suatu falsafah atau suatu pendekatan yang mencakup banyak kegiatan yang berbeda di tempat kerja yang bertujuan untuk memajukan pertumbuhan dan martabat manusia, bekerja bersama dengan saling membantu, menentukan perubahanperubahan kerja secara partisipatif dan menganggap tujuan-tujuan karyawan dan organisasi dapat berjalan bersama-sama. Penerapannya seperti program kelompokkelompak setengah otonom, program kualitas dan program komite manajemenpekerja (Flippo, 2005).

\subsubsection{Penggunaan Teknologi Informasi}

Menurut McKeown (2001) yang dimaksud dengan teknologi informasi adalah "teknologi informasi merujuk pada seluruh bentuk teknologi yang digunakan untuk menciptakan, menyimpan, mengubah dan menggunakan informasi dalam segala bentuknya." Dalam Kamus Oxford (Kadir, 2003), teknologi informasi didefinisikan sebagai studi atau penggunaan peralatan elektronika, terutama komputer untuk menyimpan, menganalisa dan mendistribusikun informasi apa saja, termasuk kata-kata, bilangan dan gambar. Secara umum Lucas (2000) menyatakan bahwa teknologi informasi adalah segala 
bentuk teknologi yang diterapkan untuk memproses dan mengirimkan informasi dalam bentuk elektronis. Menurut Senn (2004), teknologi informasi didefinisikan sebagai sebuah istilah yang merujuk ke halhal dan keahlian yang digunakan daiam penciptaan, penyimpanan, penyebaran.

Minat seseorang terhadap suatu objek akan lebih kelihatan apabila objek tersebut sesuai sasaran dan berkaitan dengan keinginan dan kebutuhan seseorang yang bersangkutan (Sardiman, 1990). Menurut Tampubolon (1991) mengatakan bahwa minat adalah suatu perpaduan keinginan dan kemauan yang dapat berkembang jika ada motivasi. Sedangkan menurut Djaali (2008) bahwa minat pada dasarnya merupakan penerimaan akan sesuatu hubungan antara diri sendiri dengan sesuatu di luar diri. Menurut Thompson et.al. (2010), pemanfaatan teknologi informasi merupakan hal yang diharapkan oleh pengguna sistem informasi dalam melaksanakan tugasnya, dimana pengukurannya berdasarkan intensitas pemanfaatan, frekuensi pemanfaatan dan jumlah aplikasi atau perangkat lunak yang digunakan.

\subsubsection{Komitmen Organisasional}

Komitmen Organisasional adalah identifikasi rasa, keterlitan loyalitas yang ditampakkan oleh pekerja terhadap organisasinya atau unit Organisasi (Gibson, 2000). Komitmen organsiasional ditunjukkan dalam sikap penerimaan, keyakinan yang kuat terhadap nilai-nilai dan tujuan sebuah organisasi, begitu juga danya dorongan yang kuat untuk mempertahankan keanggotaan dalam organisasi demi tercapainya tujuan organisasi. Rendahnya komitmen mencerminkan kurangnya tanggung jawab seseorang dalam menjalankan tugasnya. Mempersoalkan komitmen sama dengan mempersoalkan tanggung jawab, dengan demikian, ukuran komitmen seorang pimpinan yang dalam hal ini adalah kepala sekolah adalah terkait dengan pendelegasian wewenang (empowerment). Dalam konsep ini pimpinan dihadapkan pada komitmen untuk mempercayakan tugas dan tanggung jawab ke bawahan. Sebaliknya, bawahan perlu memiliki komitmen untuk meningkatkan kompetensi diri.

\subsubsection{Perilaku Kerja Inovatif}

West dan Farr (dalam West, 2006) mengatakan inovasi bisa diartikan sebagai pengenalan dan pengaplikasian ide, proses, produk atau prosedur yang baru dalam pekerjaan, tim kerja atau organisasi yang dirancang untuk menguntungkan organisasi, tim kerja atau pekerjaannya sendiri. Sejalan dengan Farr dan Ford (dalam De Jong \& Hartog, 2010) mengatakan bahwa perilaku kerja inovatif adalah bentuk perilaku yang bertujuan untuk mencapai inisiasi dan pengenalan suatu ide, proses, prosedur maupun cara pengajaran dengan metode yang baru yang berguna bagi organisasi dalam penelitian ini adalah sekolah.

Messmann (2012) mengatakan perilaku inovatif kerja adalah jumlah dari aktivitas kerja fisik dan kognitif yang dilakukan oleh karyawan dalam konteks pekerjaan mereka, baik sendiri maupun berkelompok untuk mencapai satu settugas yang dibutuhkan untuk tujuan pengembangan inovasi. Sedangkan Scott dan Bruce (1994) mengatakan inovasi adalah proses bertahap dengan aktivitas dan perilaku yang berbeda di tiap tahapnya.

Menurut De Jong dan Hartog (2010) menyatakan perilaku inovatif kerja adalah perilaku yang meliputi eksplorasi peluang dan ide ide baru, juga dapat mencakup perilaku mengimplementasikan ide baru, menerapkan pengetahuan baru dan untuk mencapai peningkatan kinerja pribadi atau bisnis. Berdasarkan definisi di atas, maka dapat disimpulkan bahwa perilaku kerja inovatif merupakan perilaku kerja individu yang melalui proses pemunculan 
ide baru untuk menghasilkan, memperkenalkan dan menerapkan ide baru yang bermanfaat bagi pribadi maupun organisasi.

\subsection{Kerangka Pemikiran Perumusan Hipotesis}

dan

Untuk mencapai tujuan, organisasi perlu mempunyai dan didukung dengan sumber daya-sumber daya yang dapat berkontribusi lebih. Tentu pencapaian tujuan tidak hanya pada saat itu saja namun harus mempunyai nilai keberlanjutan. Salah satu pendorong untuk dapat mencapai tujuan dan mempunyai nilai keberlanjutan organisasi adalah mempunyai sumber daya manusia yang good citizen (warga negara yang baik), tidak hanya bekerja dan fokus pada apa yang sedang dikerjakan secara sendiri-sendiri namun dapat bekerja secara teamwork (kerja tim) dan membangun iklim kekeluargaan dimana anggota dapat membantu rekan kerjanya satu sama lain tanpa didasari karena takut akan hukuman dan mengharapkan penghargaan yang diberikan oleh organisasi. Hal itu tentu saja tidak akan muncul secara sendirinya, melainkan perlu didorong dan dikelola melalui memelihara anggota agar mempunyai komitmen pada organisasi.

Komitmen terhadap organisasi ditentukan adanya satu pendekatan sistem manajemen untuk mengkoordinasikan dan menghubungkan potensi Sumber Daya Manusia, dimana kualitas kehidupan kerja (quality of work life) dalam organisasi sebagai suatu upaya pimpinan untuk memenuhi kebutuhan anggota maupun organisasi secara simultan dan berkesinambungan. Apabila kebutuhan telah dipenuhi, maka komitmen organisasional dapat meningkat. Dalam konsep kualitas kehidupan kerja, (quality of work life) terkandung makna bahwa tujuan organisasi harus dapat berjalan bersamasama (Flippo, 2005).

Berdasarkan uraian di atas, maka dapat dikemukakan hipotesis.
H1 : Quality of work life berpengaruh signifikan terhadap komitmen organisasional

Salah satu tantangan terbesar suatu organisasi yang ingin maju yaitu penggunaan teknologi informasi (TI). Semakin efisien organisasi menggunakan teknologi informasi, maka semakin baik organisasi itu menghasilkan informasi. Komputer yang canggih dan jaringan komunikasi merupakan alat yang efektif untuk mengelola data dalam sebuah organisasi. TI memiliki peranan dalam menfasilitasi proses pembelajaran organisasi dan pengetahuan struktur manajemen yang menjadi isu penting dalam organisasi.

Penggunaan teknologi informasi yang diharuskan di tempat kerja akan meningkatkan stres sehingga dapat menurunkan komitmen terhadap organisasinya. Pelatihan teknologi informasi masih rendah sehingga teknologi informasi membuat karyawan kesulitan dalam melakukan pekerjaan.

Berdasarkan uraian di atas, maka dapat dikemukakan hipotesis.

$\mathrm{H} 2$ : Penggunaan informasi teknologi berpengaruh signifikan terhadap komitmen organisasional.

Kualitas kehidupan kerja yang dimiliki oleh anggota dalam organisasi akan mempengaruhi dalam perilaku kerja inovatif. Perilaku kerja inovatif biasanya ditunjukkan melalui pelaksanaan tugas. Dosen dalam mengajar hanya menggunakan metode pengajaran yang konvensional (belum menerapkan metode pembelajaran yang tepat), hal tersebut mengindikasikan bahwa perilaku kerja inovatif dosen masih standar. Apabila hal tersebut masih banyak dilakukan oleh para dosen tanpa mau melakukan inovasi pembelajaran yang tepat, maka pencapaian prestasi mahasiswa tidak akan meningkat. Untuk itu diperlukan adanya perilaku kerja inovatif dari para dosem, dimana dalam pengajaran dosen menerapkan metode 
pembelajaran yang tepat dan menarik guna meningkatkan prestasi belajar.

Berdasarkan uraian di atas, maka dapat dikemukakan hipotesis.

H3 : Quality of work life berpengaruh signifikan terhadap perilaku kerja inovatif.

Penggunaan teknologi informasi di dalam lembaga pendidikan tinggi harus didukung dengan kemampuan dosen yang kompeten dalam menggunakan teknologi informasi tersebut. Hal ini dikarenakan yang mengoperasionalkan teknologi informasi sebagian besar adalah sumber daya manusia, dengan demikian organisasi perlu memperhatikan kemampuan pegawai dalam menggunakan teknologi informasi yang diterapkan. Selain itu, kemampuan kerja merupakan salah satu faktor yang sangat penting dan berpengaruh terhadap perilaku kerja inovatif dalam melaksanakan pekerjaannya. Dengan demikian teknologi informasi berpengaruh terhadap perilaku kerja inovatif dosen.

Berdasarkan uraian di atas, maka dapat dikemukakan hipotesis.

H4 : Penggunaan teknologi berpengaruh signifikan terhadap perilaku kerja inovatif.

Komitmen organisasional merupakan dorongan dalam diri individu untuk melakukan sesuatu agar dapat menunjang keberhasilan organisasi sesuai tujuan dan lebih mengutamakan kepentingan organisasi. Komitmen organisasi dapat dipengaruhi oleh beberapa faktor, dalam hal ini Greenberg dan Baron (Prayudhayanti, 2014) menyatakan bahwa komitmen organisasi merupakan salah satu bentuk sikap yang dipengaruhi karakteristik individu atau pekerja, adanya peluang pekerjaan alternatif, dan perlakuan organisasi. Karakteristik individu yang berani mengambil resiko dan memanfaatkan peluang alternatif dalam suatu pekerjaan akan menimbulkan perilaku inovatif yang berguna untuk meningkatkan kinerja individu dan organisasi.

Berdasarkan uraian di atas, maka dapat dikemukakan hipotesis.
H5 : Komitmen organisasional berpengaruh signifikan terhadap perilaku kerja inovatif.

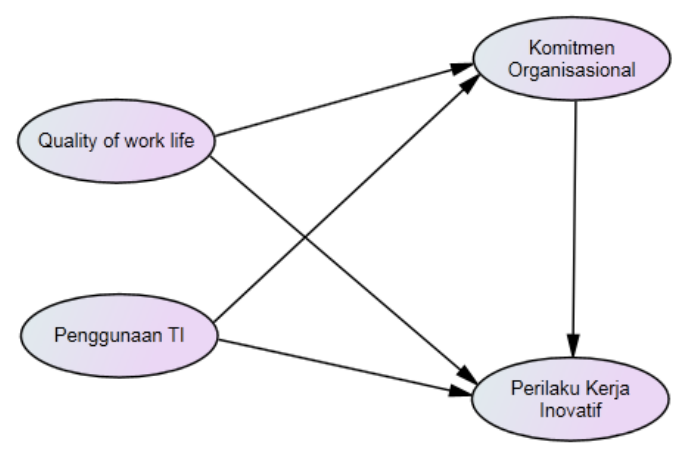

Gambar 1. Model Grafis

\section{METODE PENELITIAN}

\subsection{Populasi dan Sampel}

Populasi dalam penelitian ini adalah adalah Dosen Politeknik Pusmanu Pekalongan adalah 34 orang. Karena jumlah populasi relatif kecil, maka seluruh populasi dijadikan sebagai sampel penelitian. Menurut Arikunto (2010), apabila subjek penelitian berjumlah kurang dari 100 lebih baik diambil semua sehingga penelitiannya merupakan penelitian populasi atau menggunakan teknik sampling sensus.

\subsection{Definisi dan Operasional Variabel}

a. Quality of Work Life (QWL) merupakan salah satu bentuk filsafat yang diterapkan manajemen dalam mengelola organisasi pada umumnya dan sumberdaya manusia pada khususnya. Sebagai filsafat, kualitas kehidupan kerja merupakan cara pandang manajemen tentang manusia, pekerja dan organisasi (Sumarsono, 2004). Indikator: restrukturisasi, kemampuan, sistem imbalan dan lingkungan.

b. Penggunaan teknologi informasi merujuk pada seluruh bentuk teknologi yang digunakan untuk menciptakan, menyimpan, mengubah, dan menggunakan informasi dalam segala bentuknya (McKeown dalam Suyanto, 
2005). Indikator: domain keterlibatan, tahapan penyelarasan, pengidentifikasi lingkungan dan dimensi temporal.

c. Komitmen Organisasional merupakan sikap dan perilaku yang saling mendorong antara satu dengan yang lainnya. Pekerja yang komit dengan organisasinya akan menunjukkan perilaku dan sikap yang positip terhadap organisasinya sehingga mereka merasa senang dan nyaman dalam bekerja (Buchanan dalam Vandenberg dan Lance, 2002). Dengan indikator: komitmen afektif, komitmen continuence, dan komitmen normatif.

d. Perilaku kerja inovatif adalah jumlah dari aktivitas kerja fisik dan kognitif yang dilakukan oleh karyawan dalam konteks pekerjaan mereka, baik sendiri maupun berkelompok untuk mencapai satu settugas yang dibutuhkan untuk tujuan pengembangan inovasi (Messmann, 2012). Diukur dengan indikator: Idea Exploration (pemikiran eksplorasi), Idea Generation (pemikiran berkelanjutan), Idea Championing (pemikiran yang berhasil), dan Idea Implementation (pelaksanaan pemikiran)

\subsection{Analisis Data}

Pengukuran data dilakukan dengan menggunakan regresi. Model Matematis:

$$
\begin{aligned}
& Y_{1}=a_{1}+b_{1} X_{1}+b_{2} X_{2}+e_{1} \\
& Y_{2}=a_{2}+b_{3} X_{1}+b_{4} X_{2}+b_{5} Y+e_{2}
\end{aligned}
$$

Uji $t$ untuk membuktikan dan mengetahui pengaruh variabel bebas terhadap variabel terikat.

\section{HASIL DAN PEMBAHASAN}

\subsection{Hasil Uji Hipotesis}

a. Quality of work life memiliki nilai thitung $=6,049$ dan nilai signifikansi $($ sig $)=0,000$ lebih kecil dari 0,05 artinya quality of work life berpengaruh signifikan terhadap komitmen organisasional. b. Penggunaan teknologi informasi memiliki nilai t-hitung $=2,758$ dan nilai signifikansi $(\mathrm{sig})=0,007$ lebih kecil dari 0,05 artinya penggunaan teknologi informasi berpengaruh positif dan signifikan terhadap komitmen organisasional.

c. Quality of work life memiliki nilai thitung $=2,472$ dan nilai signifikansi $($ sig $)=0,015$ lebih kecil dari 0,05 artinya quality of work life berpengaruh signifikan terhadap perilaku kerja inovatif dosen.

d. Penggunaan teknologi informasi memiliki nilai t-hitung $=2,103$ dan nilai signifikansi $(\mathrm{sig})=0,038$ lebih kecil dari 0,05 artinya penggunaan teknologi informasi berpengaruh signifikan terhadap perilaku kerja inovatif dosen.

e. Komitmen Organisasional memiliki nilai t-hitung $=6,513$ dan nilai signifikansi $(\mathrm{sig})=0,000$ lebih kecil dari 0,05 artinya komitmen organisasional berpengaruh signifikan terhadap perilaku kerja inovatif dosen.

\subsection{Uji Koefisien Determinasi}

Besaran $\mathrm{R}^{2}$ dapat diketahui dari angka Adjusted $R$ Square yang didefinisikan sebagai koefisien determinasi dan merupakan besaran yang paling lazim digunakan untuk mengukur kebaikan (goodness of fit) sesuai garis regresi, Nilai koefisien determinasi adalah diantara 0 sampai 1 dan semakin mendekati 1 adalah semaikin baik atau fit.

Persentase kontribusi variabel Quality of work lifedan penggunaan teknologi informasisebesar $\quad 39,90 \%$ dalam menjelaskan variabel dependen komitmen organisasional, sedangkan $(100,00 \% \quad-$ $39,90 \%)=61,10 \%$ dijelaskan variabel di luar model. Adapun persentase kontribusi variabel quality of work life, penggunaan teknologi informasidan komitmen organisasional sebesar $58,60 \%$ dalam menjelaskan variabel dependen perilaku 
kerja inovatif, sedangkan $(100,00 \%$ $58,60 \%)=41,40 \%$ dijelaskan variabel di luar model.

\subsection{Analisis Uji Mediasi}

\subsubsection{Uji Mediasi I}

Uji model mediasi ini untuk menguji pengaruh variabel quality of work life $\left(\mathrm{X}_{1}\right)$ dan penggunaan teknologi informasi $\left(\mathrm{X}_{2}\right)$ terhadap komitmen organisasional $\left(\mathrm{Y}_{1}\right)$, dengan persamaan sebagai berikut :

$\mathrm{Y}_{1}=0,512 \mathrm{X}_{1}+0,234 \mathrm{X}_{2}$

Dari persamaan di atas dapat dijelaskan. Quality of work life dan penggunaan teknologi informasi memiliki nilai positif. Artinya semakin baik quality of work life semakin tinggi komitmen organisasional.

\subsubsection{Uji Mediasi II}

Uji model mediasi ini untuk menguji pengaruh quality of work life $\left(\mathrm{X}_{1}\right)$, penggunaan teknologi informasi $\left(\mathrm{X}_{2}\right)$ dan komitmen organisasional $\left(\mathrm{Y}_{1}\right)$ terhadap perilaku kerja inovatif $\left(\mathrm{Y}_{2}\right)$, dengan persamaan sebagai berikut.

$$
\mathrm{Y}_{2}=0,204 \mathrm{X}_{1}+0,123 \mathrm{X}_{2}+0,549 \mathrm{Y}_{1}
$$

Dari persamaan di atas dapat dijelaskan. Quality of work life, penggunaan teknologi informasi dan komitmen organisasional memiliki nilai. Artinya semakin baik Quality of work life, penggunaan teknologi informasi dan komitmen organisasional semakin tinggi perilaku kerja inovatif dosen.

\subsection{Analisis Jalur (Path Analysis)}

a. Pengaruh quality of work life terhadap perilaku kerja inovatif dengan mediasi komitmen organisasional, pengujian mediasi dalam penelitian ini sebagai berikut :

1. Pengaruh quality of work life ke perilaku kerja inovatif adalah 0,204.

2. Pengaruh tidak langsung quality of work life ke komitmen organisasional ke perilaku kerja inovatif adalah 0,512 x $0,549=0,281$
3. Total pengaruh quality of work life terhadap perilaku kerja inovatif adalah $0,204+0,281=0,485$.

Berdasarkan perhitungan di atas hasil uji mediasi sebesar 0,281. Artinya nilai pengaruh tidak langsung lebih besar dari pengaruh langsung quality of work life terhadap perilaku kerja inovatif. Hal ini berarti komitmen organisasional memediasi pengaruh quality of work life terhadap perilaku kerja inovatif dosen.

b. Pengaruh penggunaan teknologi informasi terhadap perilaku kerja inovatif dengan mediasi komitmen organisasional, pengujian mediasi dalam penelitian ini sebagai berikut :

1. Pengaruh penggunaan teknologi informasi ke perilaku kerja inovatif adalah 0,123 .

2. Pengaruh tidak langsung penggunaan teknologi informasi ke komitmen organisasional ke perilaku kerja inovatif adalah $0,234 \times 0,549=0,128$.

3. Total pengaruh penggunaan teknologi informasi terhadap perilaku kerja inovatif adalah $0,123+0,128=0,251$.

Dari perhitungan di atas menunjukkan hasil uji mediasi sebesar 0,128. Artinya nilai pengaruh tidak langsung lebih besar dari pengaruh langsung penggunaan teknologi informasi terhadap perilaku kerja inovatif. Hal ini berarti komitmen organisasional memediasi dan memperkuat pengaruh penggunaan teknologi informasi terhadap perilaku kerja inovatif dosen.

\subsection{Pembehasan}

\subsubsection{Hubungan Quality of Work Life dengan Komitmen Organisasional}

Hasil penelitian ini menunjukkan bahwa Quality of Work Life mempunyai pengaruh terhadap komitmen organisasional dosen di Politeknik Pusmanu Pekalongan. Hal ini memberikan makna, 
bahwa komitmen terhadap organisasi ditentukan adanya satu pendekatan sistem manajemen untuk mengkoordinasikan dan menghubungkan potensi Sumber Daya Manusia, dimana kualitas kehidupan kerja (quality of work life) dalam organisasi sebagai suatu upaya pimpinan untuk memenuhi kebutuhan anggota maupun organisasi secara simultan dan berkesinambungan. Apabila kebutuhan telah dipenuhi, maka komitmen organisasional dapat meningkat. Dalam konsep kualitas kehidupan kerja, (quality of work life) terkandung makna bahwa tujuan organisasi harus dapat berjalan bersamasama.

Sehingga dapat disimpulkan bahwa quality of work life sangat penting dalam menciptakan komitmen organisasi dosen. Hal ini mengindikasikan bahwa semakin tinggi quality of work life maka semakin tinggi komitmen dosen terhadap organisasi, begitu juga sebaliknya semakin rendah quality of work life terhadap pekerjaannya maka semakin rendah komitmen dosen terhadap organisasi.

\subsubsection{Hubungan Penggunaan Teknologi Informasi dengan Komitmen Organisasional}

Hasil penelitian ini menunjukkan bahwa penggunaan teknologi informasi mempunyai pengaruh terhadap komitmen organisasional dosen di Politeknik Pusmanu Pekalongan. Hal ini memberikan makna, bahwa Penggunaan teknologi informasi juga berhubungan dengan perilaku menggunakan teknologi tersebut dalam menyelesaikan tugas. Theory of Reasoned Action (TRA) adalah suatu teori yang berhubungan dengai sikap dan perilaku individu dalam melaksanakan kegiatan. Seseorang akan memanfaatkan teknologi informasi dengan alasan bahwa teknologi tersebut akan menghasilkan manfaat bagi dirinya. Sheppard et al. (1988) menyatakan bahwa TRA telah digunakan untuk memprediksi suatu perilaku dalam banyak hal, termasuk mempengaruhi komitmen organisasional

Sehingga dapat disimpulkan bahwa penggunaan teknologi informasi akan dapat menumbuhkan keyakinan dosen terhadap organisasi sehingga memiliki komitmen yang tinggi terhadap organisasi. Hal ini mengindikasikan bahwa semakin tinggi penggunaan teknologi informasi yang digunakan maka semakin tinggi komitmen dosen terhadap organisasi.

\subsubsection{Hubungan Quality of Work Life dengan Perilaku Kerja Inovatif}

Hasil penelitian ini menunjukkan bahwa Quality of Work Life mempunyai pengaruh terhadap perilaku kerja inovatif dosen di Politeknik Pusmanu Pekalongan. Hal ini memberikan makna, bahwa quality of work life yang tinggi memang penting dalam mewujudkan perilaku kerja inovatif, kualitas interaksi atasan-bawahan dan quality of work life berhubungan dengan perilaku kerja inovatif.

Dengan demikian dapat disimpulkan bahwa Quality of Work Life akan mempengaruhi dalam perilaku kerja inovatif dosen. Perilaku kerja inovatif biasanya ditunjukkan melalui deskripsi kerja yang menjadi tanggung jawabnya, sehingga baik ataupun buruk tingkah laku yang ditampilkan dilihat dari kemampuan dalam menjalankan tugas-tugasnya.

\subsubsection{Hubungan Penggunaan Teknologi Informasi dengan Perilaku Kerja Inovatif}

Hasil penelitian ini menunjukkan bahwa penggunaan teknologi informasi mempunyai pengaruh terhadap perilaku kerja inovatif dosen di Politeknik Pusmanu Pekalongan. Hal ini memberikan makna, bahwa pada prinsipnya penerapan teknologi informasi pada organisasi disesuaikan dengan kebutuhan organisasi, tidak harus selalu memakai teknologi terbaru, selama kebutuhan organisasi terhadap teknologi informasi yang telah ada sudah terpenuhi, 
namun jika dibutuhkan harus mempertimbangkan menerapkan teknologi informasi terbaru.

Hal ini dikarenakan yang mengoperasionalkan teknologi informasi sebagian besar adalah sumber daya manusia, dengan demikian organisasi perlu memperhatikan kemampuan pegawai dalam menggunakan teknologi informasi yang diterapkan. Selain itu, kemampuan kerja merupakan salah satu faktor yang sangat penting dan berpengaruh terhadap perilaku kerja inovatif dalam melaksanakan pekerjaannya. Sehingga teknologi informasi berpengaruh terhadap perilaku kerja inovatif dosen.

\subsubsection{Hubungan}

\section{Komitmen}

\section{Organisasional dengan Perilaku Kerja Inovatif}

Hasil penelitian ini menunjukkan bahwa komitmen organsasional mempunyai pengaruh terhadap perilaku kerja inovatif dosen di Politeknik Pusmanu Pekalongan. Hal ini memberikan makna, bahwa Perilaku kerja inovatif dapat timbul dari berbagai faktor dalam organisasi, di antaranya karena adanya kepuasan kerja dan komitmen dosen. Ketika dosen merasa puas dengan apa yang ada dalam organisasi, maka karyawan akan memberikan hasil kinerja yang maksimal dan terbaik. Begitu juga dengan dosen yang memiliki komitmen tinggi pada organisasi, akan melakukan apapun untuk memajukan lembaga pendidikan.

\section{KESIMPULAN DAN SARAN}

\subsection{Kesimpulan}

Dari penelitian ini maka dapat di simpulkan bahwa :

1. Quality of work life berpengaruh signifikan terhadap komitmen organisasional.

2. Penggunaan teknologi informasi berpengaruh signifikan terhadap komitmen organisasional.
3. Quality of work life berpengaruh signifikan terhadap perilaku kerja inovatif dosen.

4. Penggunaan teknologi informasi berpengaruh signifikan terhadap perilaku kerja inovatif dosen.

5. Komitmen organisasional berpengaruh signifikan terhadap perilaku kerja inovatif dosen Politeknik.

6. Komitmen Organisasional sebagai variabel yang memediasi pengaruh quality of work life terhadap perilaku kerja inovatif dosen.

7. Komitmen organisasional sebagai variabel yang memediasi pengaruh penggunaan teknologi informasi terhadap perilaku kerja inovatif dosen.

\subsection{Saran}

1. Hendaknya pimpinan dapat lebih efektif dalam memberikan arahan kerja yang tepat kepada bawahannya agar dapat meningkatkan perilaku kerja inovatif, selain itu pimpinan sebaiknya memberikan penghargaan kepada dosen yang memiliki quality of work life dan komitmen terhadap organisasional.

2. Hendaknya pimpinan dapat dapat memaksimalkan penggunaan teknologi informasi kepada dosen agar lebih memiliki pemikiran adanya perubahan metode pembelajaran.

\section{DAFTAR PUSTAKA}

Arikunto, Suharsimi. 2010. Prosedur Penelitian Suatu Pendekatan Praktik. Jakarta: Rineka Cipta.

Davis, Keith dan Newstrom, John W. 1994. Perilaku dalam Organisasi, Edisi 7 Bahasa Indonesia, Jilid 1. Jakarta: Penerbit Erlangga.

De Jong, J., \& De Hartog, D. (2010). Measuring Innovative Work Behavior. Creativity and Innovation Management, 19, 23-36. 
Ellitan, Lena. dan Anatan. 1998. Manajemen Sumber Daya Manusia dalam Bisnis Modern. Alfabeta. Bandung.

Flippo, Edwin B. 2005. Personnel Management. Sixth Edition. International Student Edition. New York: McGraw-Hill Book Company.

Kadir, Abdul dan Terra Triwahyuni. 2013. Pengenalan Teknologi Informasi Edisi II. Yogyakarta : Andi Offset.

Messmann, G. and Mulder, R.H. 2012. "Innovative Work Behavior in Vocational Colleges: Understanding How and Why Innovations are Developed", Vocation and Learning. Vol. 2 (1).

Prayudhayanti, Bondan Ndaru. 2014. Peningkatan Perilaku Inovatif Melalui Budaya Organisasi, Jurnal Ekonomi Bisnis, Vol.15, No.2.

Rahmad. 2013. The Analysis Of Employee Innovation Behavior Based On Four Quadrants Organizational Climate. PREDICARA. 2(1).

Sumarsono, Sonny. 2004. Metode Riset Sumber Daya Manusia. Yogyakarta: Graha Ilmu.

Suyanto. 2005.

Pengantar Teknologi Informasi

Untuk Bisnis.Yogyakarta: Andi Offset.

Undang-Undang Republik Indonesia Nomor 14 Tahun 2005 tentang Guru dan Dosen. 